\title{
Incidence, Hormonal Distribution and Postoperative Follow Up of Atypical Pituitary Adenomas
}

\author{
Atipik Hipofiz Adenomu Olgularının İnsidansı, Hormonal Dağılımı ve \\ Postoperatif Takibi
}

\author{
Ali Erdem YILDIRIM ${ }^{1}$, Denizhan DIVANLIOGLU ${ }^{1}$, Osman Arikan NACAR ${ }^{1}$, Engin DURSUN ${ }^{2}$, \\ Mert SAHINOGLU ${ }^{1}$, Tuba UNAL ${ }^{3}$, Ahmed Deniz BELEN ${ }^{1}$ \\ ${ }_{1}^{1}$ Ankara Numune Research and Education Hospital, Department of Neurosurgery, Ankara, Turkey \\ ${ }^{2}$ Recep Tayyip Erdogan University, Faculty of Medicine, Department of ENT, Rize, Turkey \\ 3 Ankara Numune Research and Education Hospital, Departmant of Pathology, Ankara, Turkey
}

Correspondence address: Ali Erdem YILDIRIM / E-mail: alierdemyildirim@gmail.com

\begin{abstract}
AIM: To assess the incidence, hormonal activity and postoperative follow up of the cases that are histopathologically diagnosed as atypical pituitary adenoma (APA) in our series.

MATERIAL and METHODS: In this study, 13 atypical pituitary adenoma cases, by the WHO 2004 criteria, among the 146 pituitary adenoma patients operated on in our clinic between January 2009 and May 2012 by endoscopic endonasal transsphenoidal approach were included.

RESULTS: In histological studies, 133 cases were diagnosed as typical pituitary adenoma (91.1\%) and 13 cases were APAs (8.9\%) of which 10 were male (76.9\%) and 3 were female (23.1\%), ranged between 27 and 80 (mean 52.7) ages. Histopathological distribution of APAs was 9 nonsecretory adenomas (69.3\%), 3 prolactinomas (23.1\%) and 1 somatostatinoma (7.6\%). Asymptomatic pituitary apoplexy was diagnosed in 4 cases (30.7\%). Eleven cases of typical pituitary adenomas (8.2\%) and 5 cases of the atypical pituitary adenomas (38.4\%) were re-operated due to tumor recurrences.

CONCLUSION: Accurate histopathological examination shows that atypical pituitary adenoma is not a rare disease. Although it is not the only determinant, APAs are more prone to recurrence than typical adenomas. In our opinion, if total resection is not possible for the patients with APA, close postoperative follow up and additional curative therapy modalities are needed.
\end{abstract}

KEYWORDS: Atypical pituitary adenoma, Ki-67 proliferation index, Tumor recurrence

öz

AMAÇ: Hipofiz adenomu tanısı ile operasyon uygulanan olgularımızdan patolojik tanısı atipik hipofiz adenomu olanların görülme sıklığı, hormonal aktivitesi ve postoperatif takipleri araştırılmıştır.

YÖNTEM ve GEREÇLER: Kliniğimizde Ocak 2009 - Mayıs 2012 tarihleri arasında endoskopik endonasal transsfenoidal yolla opere edilen 146 hipofiz adenomu olgusundan WHO 2004 kriterlerine göre patolojisi atipik hipofiz adenomu olarak saptanan 13 olgu çalışmaya dahil edildi.

BULGULAR: Histolojik olarak 133 hasta tipik hipofiz adenomu (\%91,1), 13 hasta ise atipik hipofiz adenomu (\%8,9) idi. Bu hastaların 10 tanesi erkek (\%76,9), 3 tanesi kadındı (\%23,1). Yaş dağılımı 27 ile 80 arasında idi (ortalama 52.7). Dokuz olgu nonsekretuar adenom (\%69,3), 3 olgu prolaktinoma $(\% 23,1), 1$ olgu ise somatostatinoma $(\% 7,6)$ idi. Dört olguda hipofizer apopleksi mevcuttu (\%30,7). Tipik hipofiz adenomlu hastalardan 11 tanesinde nüks saptanırken $(\% 8,2)$, atipik hipofiz adenomlu olgulardan ise 5 tanesinde nüks adenom $(\% 38,4)$ nedeniyle tekrar operasyon yapıldı.

SONUÇ: Atipik hipofiz adenomları iyi bir patolojik inceleme yapıldığında çok da nadir görülen adenom tipi değildir. Tümör rekürrensinde tek başına belirleyici olmamakla birlikte tipik adenomlara göre çok daha yüksek oranda rekürrense neden olduğu unutulmamalıdır. Bu yüzden bu hastalarda total tümör eksizyonu, eğer mümkün olmuyorsa postoperatif daha yakın takip ile ek tedavi uygulamalarının kullanılması gereklidir.

ANAHTAR SÖZCÜKLER: Atipik hipofiz adenomu, Ki-67 indeksi, Tümör rekürrensi 


\section{INTRODUCTION}

Pituitary adenomas comprise $15 \%$ of all intracranial tumors and are third in prevalence after gliomas and meningiomas (15). Twenty percent of these pituitary adenomas are diagnosed incidentally and $27 \%$ are discovered in post mortem examination $(2,4)$. The majority of pituitary adenomas consist of a benign phenotype that are slow growing and do not invade local tissues (1). A small subset of pituitary adenomas, having a more aggressive behavior, invades to bone, vascular and neural tissues or cavernous sinus, and has the potential to grow at a faster rate (10). This group of pituitary adenomas is not malignant, although, it displays aggressive phenotypes that have increased rates of recurrence despite surgical and radiation therapy. For this reason they are described as being atypical (1). Either pre-operatively through radiological findings or during the course of surgery some adenomas will show invasion of adjacent structures. These adenomas are characterized as being invasive pituitary adenomas and a small subset is referred to as atypical pituitary adenomas (5).

According to new classification criteria for endocrine tumors, released in 2004 by $\mathrm{WHO}$, pituitary tumors are classified as benign adenomas, atypical adenomas, or carcinomas (3). Based on these classifications, the diagnostic criteria for atypical adenomas include: high mitotic activity, excessive p53 immunoreactivity, and a Ki-67 proliferative index above $3 \%$ (3). The WHO's diagnostic classification has been a source of inspiration for various studies in the literature as well as a source of controversy $(6,7,8,9,11,12,17)$, but regardless, a number of studies have been published using these criteria to study the incidence and histopathology of atypical pituitary adenomas $(13,14,15)$.

Atypical pituitary adenomas exhibit aggressive clinical progression and highly invasive manifestations. For this reason, it is important to note that APAs have the capacity to cause a high degree of pathology in normal tissue as well as increased neurological deficits and difficulty of recession in surgical removal. It is also important to note that due to the rapidly dividing nature of atypical pituitary adenomas, higher than normal tumor growth, early post-operative recurrence is likely.

The goals of this study are to assess incidence rates, recurrence rates, and post-operative follow up of atypical pituitary adenomas.

\section{MATERIAL and METHODS}

Thirteen atypical pituitary adenoma cases among 146 patients harbouring pituitary adenomas operated via endoscopic endonasal transsphenoidal approach at Ankara Numune Education and Research Hospital Neurological Surgery Clinic between October 2009 and May 2012 were included in this study.

One hundred and forty-six patients who underwent surgery for pituitary adenomas were retrospectively reviewed and 13 cases diagnosed as having atypical pituitary adenomas according to WHO classification of CNS tumors (increased mitotic activity, Ki-67 proliferation index greater than 3\%, and p53 gene immunoreactivity) were selected for the study. In these patients assessment included preoperative radiological records, preoperative hormone levels, history of previous pituitary operations, preoperative invasiveness parameters, post-operative radiological records, additional post-operative treatment, and post-operative recurrences. The patients who had Ki-67 indices above 3\%, but did not present with increased mitotic activity were not included in the study.

Immunohistological studies were performed on formalinfixed and paraffin-embedded sections for the presence of ACTH, PRL, GH, TSH, FSH, LH, p53 and Ki-67. ACTH (AH 26, Thermo), FSH (N1539, Dako), GH (A0570, Dako), LH (LH01, Neomarkers), PRL (PRL02, Neomarkers), TSH (0042, Dako) Ki67 (MIB-1, Dako), and p53 (DO7, Dako) were identified with primary antibodies. In order to evaluate the positive Ki67 cells, the sections with the highest antibody counts were magnified at 400x under light microscope, and 1000 nuclear stained cells were counted. The percentage of Ki-67 positive cells was calculated (Figure $1 \mathrm{~A}, \mathrm{~B}$ ).

\section{RESULTS}

Of the 146 pituitary adenoma patients who underwent endoscopic endonasal transsphenoidal surgery, 133 patients (91.1\%) were classified as having typical adenomas and $13(8.9 \%)$ as having atypical adenomas. Of the 13 patients with atypical adenomas, 10 (76.9) were male and 3 were female $(23.1 \%)$. The age range of the patients was between 27 and 80 years (mean 52.7 years). Among 9 non-secretory adenomas (69.3\%), 3 were prolactinoma (23.1\%), and 1 was a somatostatinoma (7.6\%). Of these 13 patients, 4 were radiologically and pre-operatively diagnosed as asymptomatic pituitary apoplexy (30.7\%). Of the 4 patients with pituitary apoplexy, all were male, 2 had prolactinoma, and 2 had non-secretory adenoma (Figure $2 A, B$ ).

All 13 of the atypical pituitary adenomas were macroadenoma (diameter greater than $1 \mathrm{~cm}$ ). The pre-operative radiological images and macroscopic images of all 13 patients showed infiltration of the tumor into surrounding normal tissues (Figure $3 \mathrm{~A}-\mathrm{D}$ ). All Ki-67 indexes of masses were assessed and found to be at $3-10 \%$ with a mean value of $4.7 \%$.

In 16 of the 146 patients (10.95\%), pituitary adenomas showed recurrence within an average time of 41 months. Of the patients that experienced tumor recurrence, 11 were typical adenomas $(11 / 133,8.2 \%)$ and 5 were atypical adenomas $(5 / 13,38.4 \%)$. The typical adenomas consisted of 4 somatotropinomas (36.3\%), 3 ACTHomas (27.3\%), 2 prolactinomas (18.2\%), and 2 non-secretory adenomas. All recurrent atypical adenomas were non-secretory. Asymptomatic pituitary apoplexy existed in 4 of the 13 atypical adenoma patients (4/13). Two of the 4 apoplexy patients were prolactinomas, whereas the other 2 patients had non-secretory adenomas (Table I).

All patients, returned with recurrent pituitary adenomas, again underwent an endoscopic endonasal transsphenoidal operation for maximum resection of the tumor. 


\section{DISCUSSION}

The aim of the present study is to investigate incidence rates, hormone profiles and recurrence rates of atypical pituitary adenomas which are diagnosed according to the criteria of the latest WHO endocrine tumors classification, and to discuss the follow up of these tumors. The incidence of atypical adenomas in 146 patients, who underwent endoscopic endonasal transsphenoidal surgery for pituitary adenomas, was $8.9 \%$. Among 13 patients with atypical adenomas, 9 were non-secretory adenoma, 3 were prolactinoma and 1 was a somatostatinoma. All of these tumors were infiltrating macroadenomas. Ki-67 index ranged between $3-10 \%$ with a

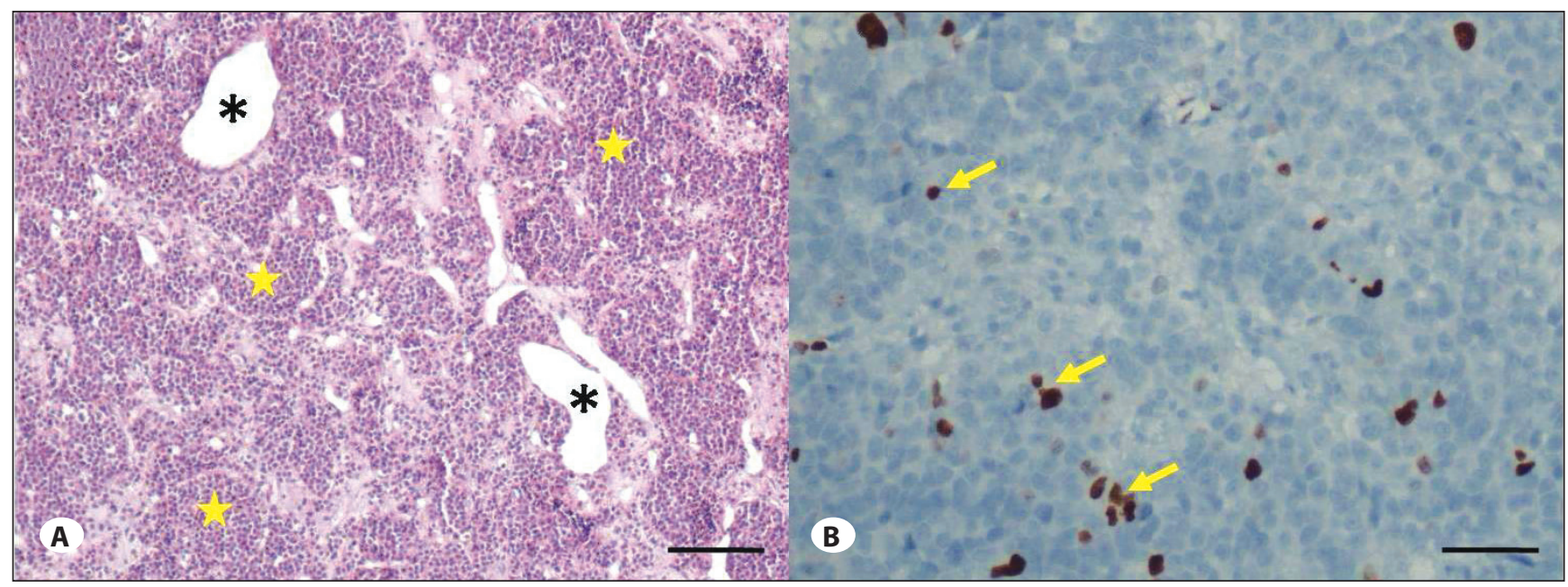

Figure 1: Photomicrographs of an atypical non-secretory adenoma. A) Islets of tumor cells with large eosinophilic cytoplasm (stars) in a vessel rich stroma (asterixes) are present (HE, X40). Scale Bar $=200 \mu \mathrm{m}$. B) Same tumor cells (arrows) with 5-8\% nuclear positive staining with Ki-67 immunohistochemical analysis (x200). Scale Bar $=40 \mu \mathrm{m}$.

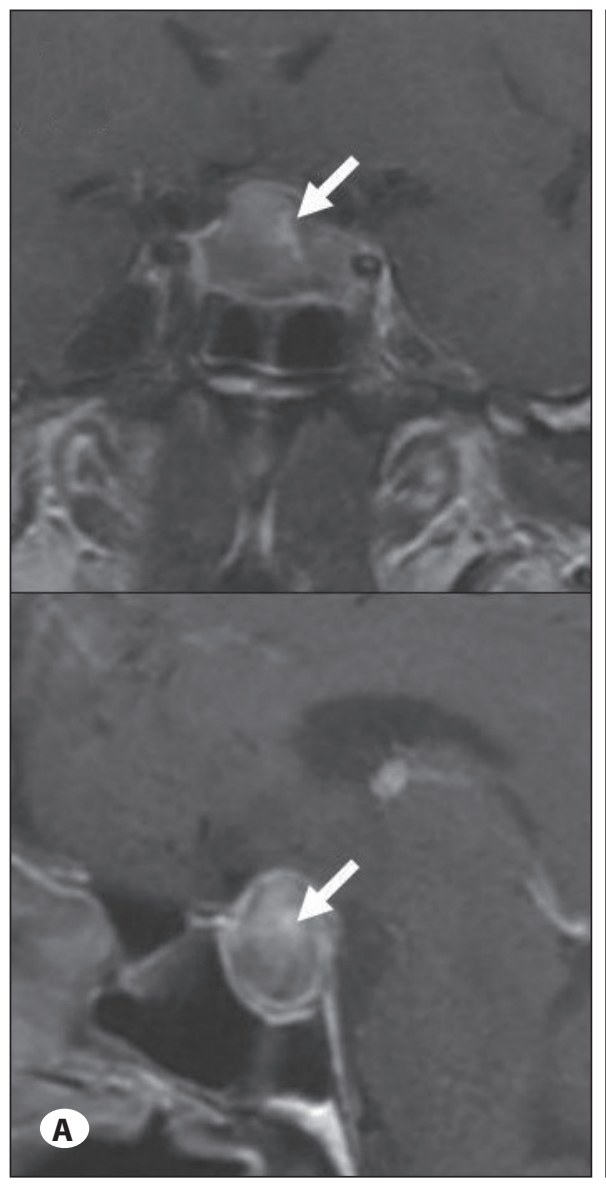

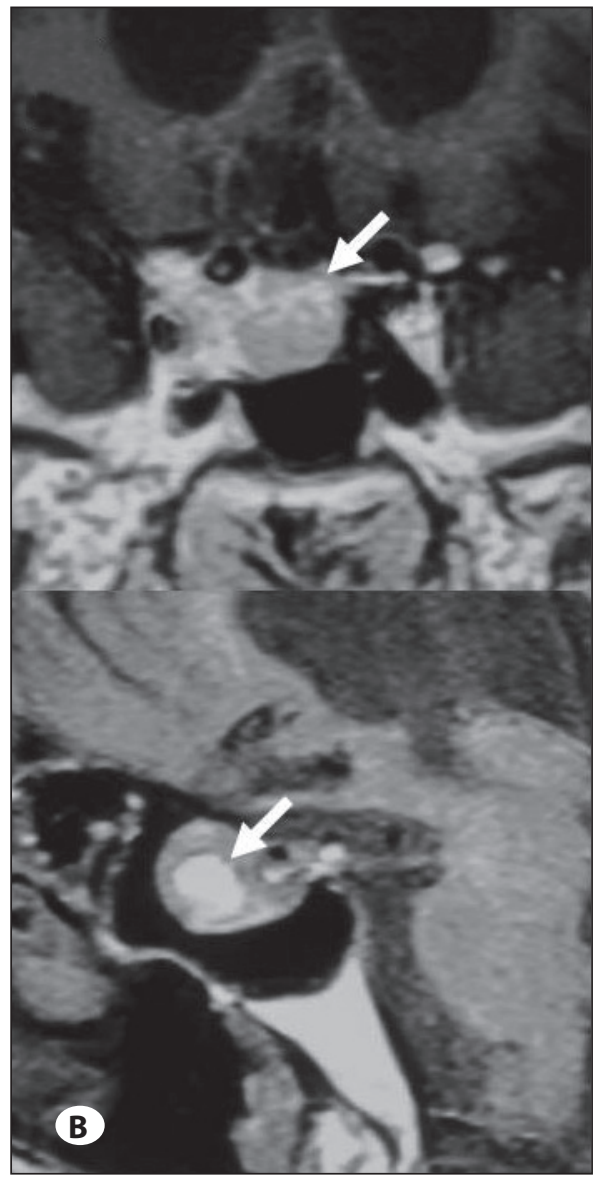

Figure 2: Preoperative Gd-enhanced coronal (upper) and sagittal (lower) MR images of 2 patients with pituitary apoplexy. Note the signal hyperintensity of blood (arrows) inside the sellar region. (A) Images of the patient with non-secretory atypical pituitary adenoma apoplexy. (B) Images of the patient with atypical prolactinoma apoplexy. 


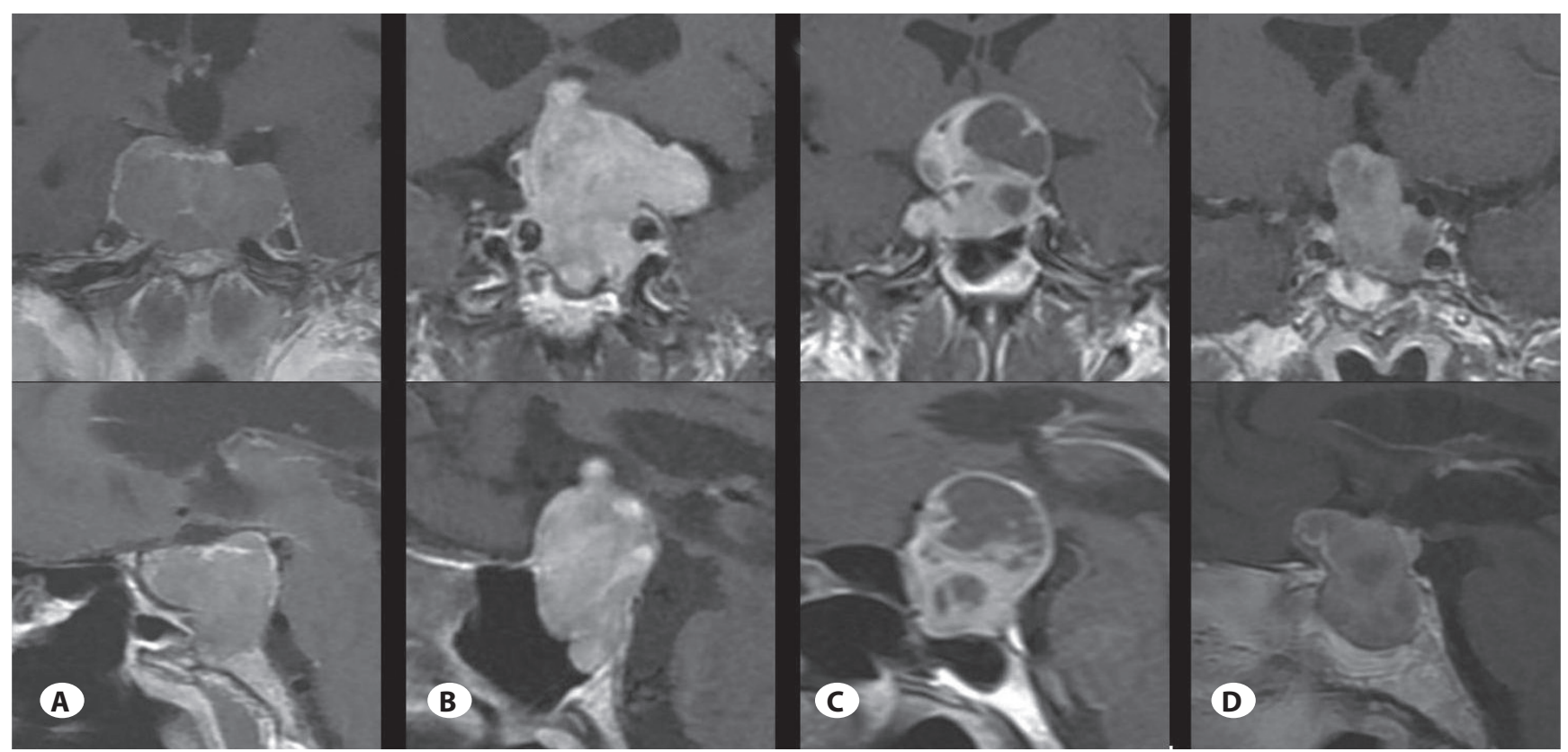

Figure 3: Preoperative Gd-enhanced coronal (upper) and sagittal (lower) MR images of 3 separate patients (A, B, C and D) with atypical pituitary adenomas. Note suprasellar, infrasellar and cavernous sinus invasions.

mean value of $4.7 \%$. Of these 13 patients, 4 presented with asymptomatic pituitary apoplexy.

Pituitary adenomas are the third most common intracranial tumor, and are seen more often in women, especially in the fourth decade (15). Most pituitary adenomas present with a benign phenotype (1). A small subset of these tumors, however, exhibit an intermediate presentation between benign and malignant biological activity. In comparison to benign tumors, these tumors with intermediate activity are generally more aggressive and infiltrate bone and surrounding vascular and neural tissues with an increased growth rate (10). Previously, this group of pituitary adenomas with more aggressive phenotypes and higher rates of recurrence was differentiated as being aggressive or premalignant adenomas (18). In the past, the functional behavior of typical and atypical adenomas were regarded as being similar in their recurrence rates, age of onset, and hormonal manifestations, with the most prominent difference was identified by MRI regarding invasion of the tumor $(83 \%$ in atypical and 45\% in typical adenomas) (18).

$\mathrm{Ki}-67$ is an antigen which is routinely examined in all pituitary adenoma specimens besides immunohistochemical staining. Increasing levels of this antigen is correlated with the speed of tumor growth, invasion of the tumor and tumor recurrence (18). In 1996, the study of Thapar et al. revealed that the $3 \%$ or more increase of Ki-67 index is significant for differentiating invasive or noninvasive pituitary adenomas and this threshold level is accepted by the WHO (16). In 2004, the WHO published a new classification scheme for the identification of atypical pituitary adenomas: Ki-67 index greater than 3\%, widespread positive p53 protein expression, and increased mitotic activity (3). Each of these atypical criteria separately display more aggressive and invasive character of the lesion but the effect on recurrence and surrounding tissue invasion of all these tree criteria is still not collectively investigated (18).

Considering previous studies, Saeger et al. 2005 identified 12 cases of atypical pituitary adenomas out of 451 total pituitary adenomas (2.7\%), Scheithauer et al. 2006 reported 6 cases of atypical pituitary adenomas out of 78 total pituitary adenomas (14.7\%), and Zada et. al. 2011 identified 18 atypical pituitary adenomas out of a total of 121 cases of pituitary adenomas $(14,8 \%)(14,15,18)$. Our study revealed 13 cases of atypical pituitary adenomas out of 146 patients (8.9\%). The percentage of our series is in concordance with the data of literature.

All pituitary adenomas were identified as having Ki-67 indices of $0-7 \%$, consistent with Scheithauer et al. findings (15). Thapar et al. presented 70 cases of pituitary adenoma masses with $\mathrm{Ki}-67$ proliferation indices averaging $4.66 \%$ (16). Zada et al. presented masses with $\mathrm{Ki}-67$ indices between 3-20\% with an average proliferation index of $7 \%$ (18). Our findings are consistent with the previous studies in that masses of patients had Ki-67 proliferation indices between 3-10\% with an average of $4.7 \%$.

Saeger et al. and Zada et al. findings show that the most common atypical pituitary adenomas are somatotropinomas, non-secretory adenomas and ACTHomas, composing more than $70 \%$ of all cases $(14,18)$. Zada et al. state that $94 \%$ of atypical pituitary adenomas in their subjects were classified as macroadenomas (18). In our study, all of atypical 
Table I: Clinical, Pathological, Radiological and Operative Distribution of 13 Atypical Pituitary Adenoma Cases

\begin{tabular}{|c|c|c|c|c|c|c|c|}
\hline Patient & Age, Sex & Hormonal Function & Pathology & Ki-67 Index & Previous Treatment & Apoplexy & Invasion \\
\hline 1 & $52, M$ & hyperprolactinemia & Prolactinoma & $>3 \%$ & Cabergoline & & IS \\
\hline 2 & $27, F$ & $\begin{array}{l}\text { hypothyroid, } \\
\text { hypocortisol }\end{array}$ & $\mathrm{N} / \mathrm{S}$ & $4 \%$ & 1xTS, 1xETS op. & & SS \\
\hline 3 & $45, M$ & $\begin{array}{c}\text { low IGF-1, } \\
\text { hypogonadism, } \\
\text { hyperprolactinemia }\end{array}$ & $\mathrm{N} / \mathrm{S}$ & $>3 \%$ & 1xTS, 1xETS op. & & IS and SC \\
\hline 4 & $39, F$ & $\begin{array}{l}\text { increased } \\
\text { GH / IGF-1 }\end{array}$ & Somatostatinoma & $2-3 \%$ & Somatostatine & & IS and SC \\
\hline 5 & $38, \mathrm{M}$ & $\begin{array}{l}\text { hypothyroid, } \\
\text { hypocortisol, } \\
\text { hypogonadism }\end{array}$ & $\mathrm{N} / \mathrm{S}$ & $3-4 \%$ & $\begin{array}{r}\text { 1xTK, 1xTS, } 1 \text { EETS } \\
\text { op. }\end{array}$ & & SS and SC \\
\hline 6 & $77, M$ & $\begin{array}{c}\text { hyperprolactinemia, } \\
\text { hypocortisol }\end{array}$ & $\mathrm{N} / \mathrm{S}$ & $5-10 \%$ & None & & SS, IS and SC \\
\hline 7 & $80, M$ & hyperprolactinemia & Prolactinoma & $>3 \%$ & Cabergoline & $(+)$ & IS and SC \\
\hline 8 & $52, F$ & $\begin{array}{c}\text { hypothyroid, } \\
\text { hypocortisol, low } \\
\text { IGF-1 }\end{array}$ & $\mathrm{N} / \mathrm{S}$ & $5-7 \%$ & 2xETS op. & & SS, IS and SC \\
\hline 9 & $44, F$ & $\begin{array}{l}\text { hyperprolactinemia, } \\
\text { hypocortisol }\end{array}$ & $\mathrm{N} / \mathrm{S}$ & $7-8 \%$ & None & & SS, IS and SC \\
\hline 10 & $50, M$ & $\begin{array}{l}\text { hypocortisol, } \\
\text { hypogonadism }\end{array}$ & $\mathrm{N} / \mathrm{S}$ & $4 \%$ & None & $(+)$ & SS \\
\hline 11 & $66, M$ & $\begin{array}{l}\text { hypothyroid, } \\
\text { hypocortisol, } \\
\text { hypogonadism }\end{array}$ & $\mathrm{N} / \mathrm{S}$ & $4 \%$ & 1xTS op. & & SS, IS and SC \\
\hline 12 & $65, M$ & hyperprolactinemia & Prolactinoma & $4 \%$ & None & $(+)$ & IS and SC \\
\hline 13 & $51, M$ & $\begin{array}{l}\text { hypothyroid, } \\
\text { hypocortisol, } \\
\text { hypogonadism }\end{array}$ & $\mathrm{N} / \mathrm{S}$ & $5 \%$ & None & $(+)$ & SS and IS \\
\hline
\end{tabular}

TC: transcranial, TS: transsphenoidal, ETS: endoscopic transsphenoidal, SS: suprasellar, IS: infrasellar, SC: sinus cavernosus, N/S: non-secretory, IGF-1: insulin like growth factor -1.

adenomas, that invade suprasellar and parasellar region, were macroadenomas. Of these patients, 9 had non-secretory adenoma (69.3\%) and 4 had hormone secreting adenoma $(30.7 \%)$. Of the four hormone secreting ones, 3 were classified as prolactinoma (23.1\%) and 1 was classified as a somatotropinoma (7.6\%).

In Zada et al. study, 11 of 18 patients underwent early postoperative screening and 4 of these patients (36\%), were found to have residual tumors within 3,5 months (18). In our study, 16 of 146 patients (10.95\%) experienced a recurrence of their tumor within 41 months. Those with recurring tumors included 11 typical adenomas (8.2\%) and 5 atypical adenomas (38.4\%). Of those with recurring typical adenomas, 4 exhibited somatotropinomas (36.3\%), 3 exhibited ACTHomas (27.3\%), 2 exhibited prolactinomas (18.2\%), and 2 had non-secretory adenomas, whereas all recurring atypical adenomas were non-secretory adenomas. These 5 patients with atypical pituitary adenoma had suprasellar and parasellar invasion, which were excised subtotally. These cases were all found to have residual tumor formation at their one-year follow up and were all treated again with endoscopic endonasal transsphenoidal surgery.

In our study, 7 of 146 pituitary adenoma patients exhibited asymptomatic pituitary apoplexy (4.7\%), with 4 being atypical adenomas (2.7\%). These four patients were male, with 2 having prolactinomas (1.3\%) and the other two having non-secretory adenomas (1.3\%).

In conclusion, our study sought to display all hormonal activities and recurrence patterns of atypical pituitary adenomas amongst total pituitary adenomas. Atypical pituitary adenomas are not as uncommon as once thought. 
While the total resection of these masses is difficult, high mitotic activity also contributes to their high rates of recurrence. For this reason, these masses should be carefully followed post-operatively and additional treatment should be provided to prolong recurrence time. Additionally, with increased mitotic capacity of the tumors, these patients exhibit bleeding within their tumors and increased rates of pituitary apoplexy. Additional studies in greater numbers of patients will be necessary to supplement the body of knowledge that is present.

\section{REFERENCES}

1. Mamelak AN, Carmichael JD, Park P, Bannykh S, Fan X, Bonert HV: Atypical pituitary adenoma with malignant features. Pituitary 14: 92-97, 2011

2. Burrow GN, Wortzman G, Rewcastle NB, Holgate RC, Kovacs $\mathrm{K}$ : Microadenomas of the pituitary and abnormal sellar tomograms in an unselected autopsy series. $\mathrm{N}$ Engl J Med 304:156-158, 1981

3. DeLellis RA, Lloyd RV, Heitz PU, Eng C (Eds): World Health Organization Classification of tumors. Pathology and genetics of tumors of endocrine organs. Lyon: IARC Pres, 2004:10-35

4. Elster AD: Modern imaging of the pituitary. Radiology 187 : 1-14, 1993

5. Ertan Y, Sarsik B, Akalin T: Tipik ve atipik hipofiz adenomlarında hormon immunreaktivite dağılımı. Turkish Journal of Pathology 25: 106-111, 2009

6. Figarella-Branger D, Trouillas J: The new WHO Classification of human pituitary tumors: Comments. Acta Neuropathol 111: 71-72, 2006

7. Grossman AB: The 2004 World Health Organization Classification of Pituitary Tumors: Is it clinically helpful? Acta Neuropathol 111: 76-77, 2006

8. Kleinschmidt-DeMasters BK: Subtyping does matter in pituitary adenomas. Acta Neuropathol 111: 84-85, 2006
9. Kontogeorgos G: Innovations and controversies in the WHO Classification of Pituitary Adenomas. Acta Neuropathol 111: 73-75, 2006

10. Kovacs K, Scheithauer BW, Horvath E, Lloyd RV: The World Health Organization Classification of Adenohypophysial Neoplasms. A proposed five-tier scheme. Cancer 78: 502-510, 1996

11. Kovacs K: The 2004 WHO Classification of Pituitary Tumors: Comments. Acta Neuropathol 111: 62-63, 2006

12. Laws ER Jr, Lopes MB: The new WHO Classification of Pituitary Tumors: Highlights and areas of controversy. Acta Neuropathol 111:80-81, 2006

13. Ogawa $Y$, Ikeda $H$, Tominaga T: Clinicopathological study of prognostic factors in patients with pituitary adenomas and Ki-67 labeling index of more than 3\%. J Endocrinol Invest 7: 581-584, 2009

14. Saeger W, Lüdecke DK, Buchfelder M, Fahlbusch R, Quabbe $\mathrm{HJ}$, Petersenn S: Pathohistological classification of pituitary tumors: 10 years of experience with the German Pituitary Tumor Registry. Eur J Endocrinol 156: 203-216, 2007

15. Scheithauer BW, Gaffey TA, Lloyd RV, Sebo TJ, Kovacs KT, Horvath E, Yapicier O, Young WF Jr, Meyer FB, Kuroki T, Riehle DL, Laws ER Jr: Pathobiology of pituitary adenomas and carcinomas. Neurosurgery 59:341-353, 2006

16. Thapar K, Kovacs K, Scheithauer BW, Stefaneanu L, Horvath E, Pernicone PJ: Proliferative activity and invasiveness among pituitary adenomas and carcinomas: An analysis using the MIB-1 antibody. Neurosurgery 38: 99-107, 1996

17. Wolfsberger S, Knosp E: Comments on the WHO 2004 classification of pituitary tumors. Acta Neuropathol 111: 66-67, 2006

18. Zada G, Woodmansee WW, Ramkissoon S, Amadio J, Nose V, Laws RE: Atypical pituitary adenomas: Incidence, clinical characteristics, and implications. J Neurosurg 114:336-344, 2011 